\title{
Digital Technologies in L2 teaching-learning in Brazil: A Critical Content Analysis
}

\author{
Roberta Gomes Leão \\ MA in Education, PPGE/UFES \\ Kyria Rebeca Finardi \\ Federal University of Espirito Santo/Cnpq
}

Received: January 10, 2021

Accepted: February 9, 2021 Published: February 15, 2021

doi:10.5296/elr.v7i1.18304

URL: https://doi.org/10.5296/elr.v7i1.18304

\begin{abstract}
The aim of this study is to reflect about the view of digital technologies in L2 teaching-learning. With that aim, a content analysis study was carried out in the Brazilian database of theses and dissertations defended between 2015 and 2019 to analyze the view of technologies in the area of L2 teaching-learning. Drawing on the Critical Theory concept of semiformation and content analysis techniques, the view/use of technologies in L2 teaching-learning was analyzed in the corpus of 22 works. Results suggest challenges in the advancement of research and critical use of technologies in L2 teaching-learning in Brazil once few studies promoted a reflexive dialogue with the participants in order make them think about the critical use of technologies in L2 teaching-learning. The study concludes with the suggestion for more investment in the human formation process through the critical use of technologies in the teaching-learning of L2.
\end{abstract}

Keywords: Digital Technologies, L2 teaching-learning, Critical theory

\section{Introduction}

Social distancing measures imposed by the 2020 pandemic to minimize the spread of the virus affected the educational system disrupting face-to-face classes which had to be replaced by remote teaching-learning (Williamson, Eynon \& Potter, 2020). The migration of activities to the online mode brought a series of consequences for education in general and for the teaching-learning of Additional Languages (L2) (Note 1) in particular.

The uncritical use of technology and digital tools for the teaching-learning of L2 can cause a false sense of appropriation of the language and its culture. Before the Covid-19 pandemic, studies (for example Vieira \& Finardi, 2018) showed that though technology can aid the 
teaching-learning of L2, its use alone cannot guarantee L2 acquisition. Considering that the use and impact of digital technologies/internet in social and educational practices increased considerably during the period of social isolation imposed by the pandemic, we think it is important to reflect about how this use is aiding or preventing the critical education/formation of society.

Digital technologies enable us to deal with large flows of information in a relatively accessible way (Finardi \& Porcino, 2014; Finardi et al., 2014). Also, the use of digital technologies and the internet expanded access to information affecting the way we relate to and in the world (Finardi \& Porcino, 2014), as well as the way we use, learn and teach L2.

Considering this panorama, this paper proposes a reflection on the use and impact of digital technologies in the teaching-learning of L2. With that aim, we discuss the view/use of technologies in L2 teaching-learning by drawing on critical theory in a bibliographic review of theses and dissertations produced in Brazil between 2015 and 2019, that is, four years before the pandemic outbreak.

We assume that the critical teaching-learning-use of L2 can promote the expansion of horizons, by building new meanings in addition to those that can be produced in the native language (and culture) (Jordão, 2005; 2006). However, during the pandemic we have witnessed the transformation of teaching-learning of L2 into a commercial activity with the growth of investments in tools and applications (apps) for language learning (Bardeen \& Cerpa, 2015; Williamson, Eynon \& Potter, 2020). This marketization of tech tools and educational products are not always informed by research or theories about the best pedagogical uses of technology. This is because technology applied to L2 teaching-learning not always promotes interaction and L2 use in a critical way (Finardi, Vieira \& Leão, 2019), thus collaborating to the semiformation of users, citizens and thus society.

\section{Critical Theory of Society}

We draw on the Critical Theory of Society in general and Adorno's view of semiformation that is, the belief or misconception that one has full knowledge of a subject- in particular, to analyze the use/view of technology in L2 teaching-learning in research produced in Brazil.

Adorno's historical context is one of unidirectional devices/artifacts such as the radio and television which often represented the only means to acquire contents (Adorno, 1995). Considering the large audience of television and the number of hours spectators/consumers spent in front of the TV set, Adorno suggested that the TV had the potential of either forming or deforming people (Adorno, 1995), depending on how individuals "consumed" those contents.

Internet access, especially after the advent of the Web 2.0, enabled the access and production of online contents in unprecedented ways. However, according to Selwyn (2014), we must be careful with this positive view of the internet as a space where anyone can learn and become a content creator for very often people are mere consumers of contents in an uncritical way. This is because digital technologies have also been used to transmit dominant ideologies and fake news.

The emergence of influencers, bloggers and youtubers, so popularized (and even trivialized) during the pandemic, suggests that the access to online contents does not always guarantee 
access to reliable or relevant information. In Brazil, content creators published advertisements about what should be consumed, dictated a lifestyle to be followed and many of them acted as propagators of fake news and contents based on their own opinions during the pandemic. Most of these contents posted online had no scientifically supported arguments, thus working for the discrediting of science and journalistic news in the opposite direction of what one may see as critical education/formation of society.

In this sense, we can see the potential relationship between digital technologies and ideologies of individualism, neoliberalism and the new economy, playing the role of maintaining the dominance of these values and interests in education and the formation of society. Considering the potential of ideologies to serve the interests of the market, we must exercise caution in relation to the view we have of it as warranted by research found on the use of digital technologies in education reflecting such perspectives based on the notion of the "empowered individual" (Selwyn, 2014).

The most cited Brazilian educator, Freire (2011), defended critical thinking and the exchange of experiences and knowledge between teacher and students as a way to emancipate education and individuals. Freire's notion of libertarian education promotes dialogue for the co-construction of knowledge and critical thinking to liberate and empower individuals and informs this study.

In times of social isolation and hyperconnectivity promoted by the pandemic, we propose the reflection on the impact that the use/view of technologies in L2 teaching-learning can have on the current configuration of society. Because we are much more exposed to the ideology propagated by the cultural industry and apparently we have become defenseless in relation to its products assuming that we cannot exercise virtual distancing measures once we are immersed in this virtual reality where we maintain our social relations.

If the web 2.0 brought us the possibility to participate in this formation or deformation of society more broadly through the use of the internet, we seek here to encourage active and critical participation in this virtual space through the critical reflection on the contents and ways of relating to the world in this new virtuality/reality.

A semiformed subject believes to be fully educated, when in fact, his/her knowledge is conditioned to what is offered by the cultural industry, in a kind of merchandise to attend formation demands, causing the false feeling that the consumption of cultural goods will bring more qualification. This access to information is not enough to promote the emancipation or autonomy of thought in subjects so that they are able to critically analyze what is consumed in their historical-social contexts (Adorno, 1992; Adorno, 2002; Maar, 1995; Maar, 2003; Petry, 2015). When this superficial relationship is reinforced by what is consumed, reflection becomes disposable, quantity overrides quality, defined as the social value attributed to the product by the cultural industry.

The quantity of cultural products consumed does not guarantee the quality of the subject's learning. As long as the value of this learning is associated only with the isolated accumulation and not with its role within the culture itself and with what refers to being human, it will be just another way to promote the regression in the formation, that is, to promote the semi-formation (Adorno, 1992; Loureiro, 2007). 


\section{MInstitute Macrothink $_{\text {Int }}$}

Currently, we deal with this situation in relation to digital technologies, especially those of the Web 2.0 with its mobile users allowing a wide range of contents to be accessed at any time and/or place. More advanced than the television, the technique of transmitting content from new digital technologies is unquestionably modern, however only the one who has reached an evolved consciousness is able to reflect whether the content broadcasted by these new technologies is modern or not, once that process requires critical thinking (Adorno, 1995).

As the cultural industry operates in the mass production of cultural products just for the purpose of making a profit (Adorno \& Horkheimer, 2002), thought is a mere formalism, a technical rationality. The over emphasis on technical rationality leads society to a state of domination rather than resistance. It is the opposite of cultural formation. The increase in the amount of L2 learning-teaching products in a functional, structural and technical fosters the transmition of ideology by the cultural industry thus transforming the L2 teaching-learning-use into just one more product rather than affording the true understanding of the culture and critical aspects associated with L2 learning-teaching-use.

Digital evolution has been happening since the 1970's when the internet was already known in the military and scientific fields, financed with public resources though only adult and trained subjects could use it (Ponte, 2017). It was only a few decades after the emergence of the world network or the World Wide Web in 1989 that the internet was made available to the general public through a commercial supplier.

In its first phase, that of the Web 1.0, information was transmitted in an unidirectional machines like radios, televisions and websites, the latter accessible only by desktop computers. The first transformation was the arrival of broadband and wi-fi, amplifying access options, culminating, in the second phase of the Web 2.0 in the possibility for users to participate in the production of online contents. This phase was marked by the emergence of new mobile technologies, also marking the popularization of interactive sites and social networks such as Blogger, Wikipedia, My Space, Facebook, Flicker, Youtube and Twitter (Ponte, 2017).

With the popularity of social networks and their possibilities of interaction between subjects located in geographically distant places, giant companies in the digital economy have emerged investing in the development of personalized algorithms capable of identifying the profile of users, marking the transition to the Web 3.0 (Ponte, 2017). Thus, what differentiates the Web 2.0 from the Web 3.0 is that in the latter our choices of research and entertainment have become a profitable channel for the advertisement of products that meet our consumer profile, reaching us automatically and subtly as if by chance, when we access the internet.

The arrival of the Web 4.0 marks the intensification of the flexibility of the digital experience, with its ubiquity and intuitiveness in everyday objects (Ponte, 2017). In addition, the Web 4.0 is characterized by allowing the storage of information in clouds - virtual spaces where it is possible to access, edit or store information remotely through different digital technologies and also a "digital living" exposing people's living to the judgment of others (Ponte, 2017) as is the case of the Brazilian version of the reality show Big Brother (Note 2) and the like.

"Digital living" has become a reality since 2020 with the emergence of the Covid-19 
pandemic, impacting the way we relate to and in the world and also the way we teach, learn and use L2. Considering that many cultures did not have the habit of integrating digitalization in teaching, nor even policies for the use of digital tools for that matter (Wyatt, 2020), as is the case of several educational contexts in the Brazilian reality (Có, Amorim \& Finardi, 2020), there was a great struggle to ensure that classes are maintained in an emergency remote format during the pandemic. The adoption of distance learning in the emergency remote format has become an open field for (financially oriented) experiences and development of the educational technology industry (Williamson, Eynon \& Potter, 2020) calling for critical analysis of these possibilities that partially motivates the present study.

The transition from the Web 1.0 that allowed unidirectional access to online contents to the Web 2.0 that allows individuals to act not only as consumers of information, but also as producers, inspired Bruns (2006) to coin the term "produsage" highlighting the blurring between producer and user in this new context. "Digital living" has reconfigured everyday practices and experiences, blurring boundaries between the actual/real/virtual. The produsage of information/contents suggests a hybridism characteristic of our era and that affects interactions and identities in a world where the borders between users, consumers and producers from different regions are increasingly erased (Mendes \& Finardi, 2018). In the same way, the boundaries between teaching-learning-using L2 is also becoming more blurred as we gradually carry out these activities more and more online, justifying our use of this term as one in this study.

Regarding the creation of technological products, we can think of two categories of analysis, namely: evolutionary objects and revolutionary objects. The evolutionary category refers to the limitations of other products already available in the market that require adaptations with more modern resources in order to supply the existing needs in society. The revolutionary category refers to those objects that create new needs in society based on factors that have never been explored before, thus configuring a more complex process of creation (Bardeen \& Cerpa, 2015).

We can view the current moment as a symbiosis between these two movements in the sense that educational technologies are undergoing evolutionary changes, while their use is undergoing a revolutionary movement, with the migration of face-to-face practices to virtual environments that will likely last in the post-pandemic context with new adaptations to the "new normal" reality. In this sense, we see hybridism as a characteristic of our era, as it is notorious that we are not yet prepared (or willing) to live a totally virtual life, just as we will no longer have a life completely alien to the virtual world in a post-pandemic "new reality".

The market, while creating needs, promotes the desire for consumption in mass society. In this sense, it seeks to develop updates and innovations for its products and services, especially with regards to digital technologies (Bardeen \& Cerpa, 2015). The speed with which digital technologies are updated and innovated imposes a certain difficulty in researching these artifacts, since the pace of technological evolutions and revolutions is very fast (Han, 2018, Paiva, 2013), while the slow processing is characteristic of research. The former runs out of time trying to get ahead to meet or advance the market expectations, while the latter needs time to analyze, reflect and conceive. That having been said, research on digital technologies in general is always "lagging behind", although insights from this 
research may help to understand the present. This is the case, for example, of this study, which despite having chosen a period of analysis between 2015 and 2019, hopes to shed light in the understanding of technologies in L2 teaching-learning-use and in the post-pandemic world.

The choice of Brazil as an illustration of the microcosmos analyzed here is justified in Diniz de Figueiredo and Martinez' (2019) invitation for researchers to reveal their locus of enunciation as a way to fight epistemological myopia to decolonize scholarly knowledge. The two authors of the present paper are Brazilian teachers of English who have developed research on the use of technologies in L2 within that context (e.g. Có, Amorim \& Finardi, 2020, Mendes \& Finardi, 2020, Castro, Hildeblando Jr. \& Finardi, 2019, Finardi, Vieira \& Leão, 2019, Leão, Taquini \& Finardi, 2019, Castro, Mariano \& Finardi, 2018, Vieira \& Finardi, 2018, Finardi \& Vieira, 2017, Finardi, Leão \& Amorim, 2016, Finardi, Leão \& Pinheiro, 2016, to cite a few). Moreover, the political and economic crisis in Brazil was aggravated during the pandemic because of the spread of fake news, showing that the Brazilian society was deeply impacted by the process of semiformation, as seen in the ways in which the Covid pandemic was treated in social medias and the news in that country, affecting the rate of social isolation and discreditation of the disease first and the vaccine's efficiency (Note 3) after.

It is also necessary to consider the time between the study/research and the time taken for it to reach society, through teacher training and education. Before the pandemic, the use of technologies in education was still far behind the use of technologies in everyday society (Finardi \& Teixeira, 2013), as can be seen in the rules created to limit or ban the use of digital technologies in the form of computers, notebooks and mobile devices in the classroom (Fadini, 2016; Finardi \& Mendes, 2017). For this reason, before the pandemic we saw a gap between the teaching approaches offered by the school and the reality outside the school walls regarding the use of digital technologies. With the tendency of border between home-school to fade after the pandemic, it is important to reflect about the critical use of technologies in this new reality.

Regarding the use of technology in education, Arruda (2013) argues that it is very difficult to draw the line between what is "entertainment" and what is "education", which further complicates research on the use of technology in education. The switch to remote education during the pandemic highlighted the difficulty in using a device that was previously used only for entertainment, now as an educational tool. It is important to see the virtual space as also one of learning (Mendes, 2017) and for that we advocate for the re-education and reframing of the way we view and deal with digital technologies for pedagogical purposes or in educational contexts.

From an economic point of view, the difficulty in studying the use of digital technologies in the teaching-learning-use of L2 cannot prevent progress, especially given the fact that the companies that develop technological products are evolutionary and revolutionary, and as such they constantly seek to understand (and even advance as in the Web 3.0) consumer wishes through the analysis of their profiles to make profit (Bardeen \& Cerpa, 2015).

At this point we ask ourselves why the schooling remained, at least until the pandemic, focused on traditional and analogic contents despite the fact that learners were already 
familiar with digital contents outside the school walls (Arruda, 2013). While the tools and apps for teaching-learning of L2 are constantly evolving to solve the limitations of their previous versions from a structural point of view (Bardeen \& Cerpa, 2015), there is still a long way to go before the pedagogical or linguistic limitations of these technological tools are addressed (Finardi et al., 2019).

Before the pandemic and in an attempt to incorporate digital technologies in mainstream education, a series of problems were already reported by teachers and students in Brazil (Finardi et al., 2014). Teachers complain about the difficulties to schedule classes in the computer labs and the reduced hours in L2 classes. Also, students complained about teachers' lack of knowledge of and skills with new digital technologies (Finardi et al., 2014).

Adding to all these problems, the incorporation of digital technologies in the teaching of L2 is not a simple task due to the inconsistency between ergonomic and pedagogical aspects of educational software such as the lack of feedback and diagnosis of linguistic progress and content-based methodologies that do not address ergonomic, linguistic and pedagogical needs of learners (Prebianca, Dos Santos Júnior \& Finardi, 2014; Prebianca, Vieira \& Finardi, 2014).

With the sudden transition from school activities to virtual environments promoted by the pandemic, the aforementioned complaints became more evident, as well as the problems of social inequality in a context where not all schools and teachers have material and training to create classes in the remote/online mode, nor all students have adequate access or physical space/conditions for this type of teaching-learning mode.

Before the pandemic, issues of product and service decay were already observed due to their incompatibility with the needs of society, rendering some of these products obsolete (Bardeen \& Cerpa, 2015). In view of the symbiosis of evolution and technological revolution, it is necessary not only an adaptation of educators and students, but also of methods and the system as a whole, to prevent them from becoming obsolete.

Society is suffering the impacts of information overload with the growth of information with the reduction in capacity for judgment (Han, 2017, p. 17). Typing does not have to include a concern about syllable separation or spelling since the machine does it automatically, but we still have to focus on other reading skills such as digital literacy (Coscarelli, 2017), understood here as the ability to understand and interpret the various media, contents, texts and hypertexts available online in such a way that the subject is able to critically understand what is consumed through digital devices.

We have followed an evolutionary line with no return whereby digital technologies are incorporated into our being, relating and doing. The way of dealing with technologies will affect our social role making a difference in the post-pandemic scenario. In what concerns the use of digital technology in education, we feel that it is unlikely that it will replace the teacher though a teacher who does not use technology may be replaced by another one that does. We invite readers to think about the kind of educators we will have in the post pandemic scenario. How will education be affected by the cultural industry/Mass Media? So as to reflect about the impact of technology in L2 teaching-learning-use in particular, the following section describes the methodology employed in the study. 


\section{Methodology}

The study aimed to analyze the view of technology in L2 teaching-learning research produced in Brazil. With that aim, a content analysis (Bardin, 2011) was carried out in a corpus composed of theses and dissertations available in the Brazilian academic database. Mixed methods design (Dornyei, 2007) were used to collect and analyze quantitative and qualitative data during the four steps of identification, localization, compilation and filing of information. The analysis was based on the use of digital technologies in the teaching-learning of L2 in a corpus composed of theses and dissertations defended between 2015 and 2019 and found in the portals of Coordination for the Improvement of Higher Education Personnel (CAPES in Portuguese) and the Digital Library of Theses and Dissertations (BDTD in Portuguese).

The combination of descriptors used in the search in the portals was: "Technology; Foreign language teaching", "Technology; Teaching L2", "Technology; Additional Language Teaching", "Virtual; Foreign language teaching", "Virtual; Teaching L2", "Virtual; Additional language teaching", "Internet; Teaching of L2", "Internet; Foreign language teaching", "Internet; Additional language teaching “, “ Digital Technologies; Teaching of L2”, "Digital Technologies; Additional language teaching" and finally we added the descriptor" Technology; Education; Language". In the CAPES portal, the semicolon sign (;) between words was replaced by "AND" to achieve a more refined result. Thus, studies that addressed the topics of the selected descriptors distinctly did not appear in the search result.

From the results obtained with each combination of descriptor, we surveyed the number of selected works. The percentage of works in the Education area (22) was significantly lower than that of Linguistic Studies (86), but together composed a corpus of 108 studies that allowed the analysis of how digital technologies were treated in L2 teaching-learning research in Brazil in that period. More specifically, we sought to analyze the content of Brazilian researches about view/use of technologies in L2 teaching-learning. For this reason, we chose the studies in Education because the number of their production was lower than Linguistics Studies, so, it was possible to view the gaps that were not explored yet by Education researchers.

The organization of the works was made according to the similarity criterion. The titles, authors, descriptors and platform of the works selected for the content analysis are initially presented in a table format to facilitate identification of results that feed the analysis section. In total, 22 studies that met all the criteria for qualitative analysis were selected for this study.

\section{Results and Analysis}

To organize the quantitative data, we separated the works by area of knowledge, in order to have a clearer notion of the scientific production of each area with respect to the approach of digital technologies and L2 in them. The results showed that there are not many areas of knowledge addressing this topic. On the BDTD platform, for example, we found the following post-graduate programs: Linguistic Studies, Education, Human Development Processes and Health, Media and Technology and the Intelligence Technology and Digital Design program.

With the exception of the descriptor "Digital Technologies; Foreign language teaching", a 


\section{Ml Macrothink}

greater number of works is produced by the Linguistic Studies area which presented a total 62 works, an average of 12 studies per year (inside our chronological cut). In the Education area, we found a total of 18 studies, an average of 3,8 works per year. The comparison of the scientific production between areas shows that the Linguistic Studies and Education areas together account for more than half of the total number of areas found.

In the case of works in the area of Technology of Intelligence and Digital Design and Media and Technology we found three works whereas in the area of Processes of Human Development and Health only two works were found. This pattern was also repeated in the results of the survey of works on the CAPES platform, where works from other areas appear in smaller quantities than in the areas of Linguistic Studies and Education. The chronological analysis shows that the area of Linguistic Studies presented a result of 24 works, an average of 4,8 defenses per year, while the area of Education, only four works were found, two defended in 2015 and the others in 2017. We also identified studies in the areas of Media and Technology and Management and Technologies applied to Education, with one case each.

The preliminary bibliographic data collection to form the corpus showed that some themes were repeated: Digital Tools for Teaching-Learning-Use of L2, Mobile Learning, Distance Education, Gamification, Teacher Initial Education and Internationalization. Because of the prevalence of these themes in our data, we used the same themes during the content analysis of the corpus. Results of the content analysis of the corpus are summarized in Table 1 relating the type of use of technology in L2 teaching-learning, that is, whether it was critical or merely instrumental.

Table 1. Summarized Results of the Content Analysis of Corpus

\begin{tabular}{|l|l|}
\hline \multicolumn{2}{|l|}{ Digital Tools for Teaching-Learning-Use of L2 } \\
\hline Author & Synthesis \\
Botero & $\begin{array}{l}\text { Analyzed hypermedia materials in four Spanish textbooks. Only one of the } \\
\text { analyzed materials addressed cultural aspects of the Spanish language, but } \\
\text { without any hypermedia resources, that is, it had no relationship with digital } \\
\text { technologies. In addition, due to the restrictions on access to content } \\
\text { (available only to payers), contact with L2 through this type of digital } \\
\text { technology is limited to publishers. }\end{array}$ \\
\hline $\begin{array}{l}\text { Mesquita } \\
(2016)\end{array}$ & $\begin{array}{l}\text { Created a blog for Spanish language classes promoting the exchange and } \\
\text { construction of knowledge through critical reflections/dialogue established } \\
\text { between researcher, students and teacher. The critical use of the blog } \\
\text { resulted in an increase in students' interest in the language, in this case } \\
\text { Spanish, and in technologies as a pedagogical resource. }\end{array}$ \\
\hline $\begin{array}{l}\text { Caramano } \\
(2017)\end{array}$ & $\begin{array}{l}\text { Elaborated video lessons for teaching English for Adults (EA) in an attempt } \\
\text { to minimize the distance in L2 for adults. The video lessons were not } \\
\text { implemented, so it was not possible to analyze the educational experience } \\
\text { with video lessons. }\end{array}$ \\
\hline
\end{tabular}




\begin{tabular}{|c|c|}
\hline Vogt (2015) & $\begin{array}{l}\text { Analyzed the use of digital whiteboards in private language institutes } \\
\text { suggesting great potential to explore the L } 2 \text { and its culture in class through } \\
\text { internet access. Results also sugest that the digital whiteboard is very } \\
\text { centered on the teacher and not amply available in schools due to its high } \\
\text { cost. }\end{array}$ \\
\hline Lima (2016) & $\begin{array}{l}\text { This experimental study analyzed the use of digital technologies in L2 } \\
\text { learning. The control group did not have access to any type of digital } \\
\text { technologies, while the experimental group used all the technological } \\
\text { resources available at the school. The use of digital technologies during the } \\
\text { L } 2 \text { classes did not have a significant influence on students' performance but } \\
\text { the dialogue between teacher-students led the researcher to conclude that the } \\
\text { practices with digital technologies may help students form a critical view of } \\
\text { technologies. }\end{array}$ \\
\hline Sgorla (2016) & $\begin{array}{l}\text { This study analyzed reports of participants in relation to their experience } \\
\text { with digital technologies. Among the points reported by them, we highlight } \\
\text { the need for more investments in accessibility programs to digital media in } \\
\text { schools, the production of new digital teaching materials and the continued } \\
\text { qualification of teachers, so that they feel better able to deal with the } \\
\text { overload of information available online. }\end{array}$ \\
\hline Rech (2018) & $\begin{array}{l}\text { Like the previous study, this one reports participants' experience in relation } \\
\text { to the use of digital technologies in L } 2 \text { teaching-learning. Students reported } \\
\text { using more digital technologies outside the school than inside or in } \\
\text { pedagogical practices. }\end{array}$ \\
\hline $\begin{array}{l}\text { D’Ambrósio } \\
(2017)\end{array}$ & $\begin{array}{l}\text { This study analyzed the HágaQue software, which proved to be a relevant } \\
\text { resource of L } 2 \text { culture. The process of creating stories involves various } \\
\text { aspects of L } 2 \text { beyond the mere linguistic/instrumental only. Another factor } \\
\text { that contributed to an experience of critical use of technologies was the } \\
\text { collaboration between students during the process. }\end{array}$ \\
\hline Mello (2018) & $\begin{array}{l}\text { The study did not use any specific digital tool, and so the perspectives of the } \\
\text { research participants in relation to technology were analyzed. Results } \\
\text { highlight the difficulty in finding schools willing to collaborate in research. } \\
\text { Participants stressed the benefits of using digital technologies in schools } \\
\text { despite the structural difficulties associated with it. }\end{array}$ \\
\hline $\begin{array}{l}\text { Raimundo } \\
\text { (2017) }\end{array}$ & $\begin{array}{l}\text { Participants did not seem aware of the advantages that digital technologies } \\
\text { provide for education, highlighting the importance of investing in the } \\
\text { maintenance and purchase of equipment that meet the demand of each } \\
\text { school. This can be a step towards solving organizational problems such as } \\
\text { reserving computer labs or specific materials that are shared with the entire } \\
\text { faculty. Also, initial and continuing education is necessary to equip teachers } \\
\text { to use digital technologies. }\end{array}$ \\
\hline
\end{tabular}




\begin{tabular}{|c|c|}
\hline \multicolumn{2}{|c|}{ Mobile Learning } \\
\hline Author & Synthesis \\
\hline $\begin{array}{l}\text { Honorato } \\
(2018)\end{array}$ & $\begin{array}{l}\text { Analyzed the Duolingo app as a teaching-learning-use resource for L2. } \\
\text { Duolingo presents several points that need to be improved for an effective } \\
\text { appropriation of the L2 as it does not address cultural aspects nor } \\
\text { encourages the creative use of L2, focusing mainly on the instrumental } \\
\text { aspect of the language. The reinforcement through awards achieved in the } \\
\text { app can give a false sensation of learning thus contributing to the } \\
\text { semiformation of the L2. }\end{array}$ \\
\hline Liz (2015) & $\begin{array}{l}\text { Created the High Fly Learning app as a support to L } 2 \text { classes. Because it is } \\
\text { an app that follows the principles of a class where the content is inserted by } \\
\text { the teacher, the critical use of the app depends on the teacher leading us to } \\
\text { conclude that the mediation of the teacher is essential to avoid } \\
\text { semiformation in the use of technologies in L2 teaching-learning-use. }\end{array}$ \\
\hline $\begin{array}{l}\text { Rapaport } \\
(2016)\end{array}$ & $\begin{array}{l}\text { Analyzed four apps (Duolingo, Memrise, Mindsnacks and Busuu) for } \\
\text { teaching-learning-using L2 in terms of their technical characteristics. With } \\
\text { the exception of Duolingo, the other three offer limited activities for users } \\
\text { who only join the free plan. The Memrise app works only with vocabulary } \\
\text { memorization, Mindsnacks only activities with short phrases and Busuu is } \\
\text { the only one that offers conversation activities in L2 with native speakers, } \\
\text { and we consider that because of this, it is the only app that does not to } \\
\text { suppress culture in the process of learning L2. All apps offered preparatory } \\
\text { activities for proficiency exams or entrance tests at national and foreign } \\
\text { universities, which made us question how apps that offer very simple } \\
\text { activities or just memorization can offer enough preparation for the user to } \\
\text { perform well in such tests. These apps are more instrumental than critical } \\
\text { though they can aid L2 learning with the mediation of the teacher. }\end{array}$ \\
\hline Lopes (2018) & $\begin{array}{l}\text { Analyzed the Minha Spain app, which is not a tool for language learning, } \\
\text { but for L2 (Spanish) culture. The teacher's presence is essential to mediate } \\
\text { L2 learning through the L } 2 \text { culture. }\end{array}$ \\
\hline $\begin{array}{l}\text { Roppel } \\
(2017)\end{array}$ & $\begin{array}{l}\text { Analyzed Duolingo through the students' perspective who claimed that they } \\
\text { like Duolingo for bringing exercises with simple resolutions and for being } \\
\text { also a means of entertainment and L } 2 \text { practice that can be used any } \\
\text { time/place. The lack of realization on the part of students, that Duolingo } \\
\text { offers an instrumental learning of the L } 2 \text { suggests the need of teacher } \\
\text { mediation to enable a more critical process of L } 2 \text { learning. }\end{array}$ \\
\hline \multicolumn{2}{|c|}{ Distance Education } \\
\hline Author & Synthesis \\
\hline Motta (2017) & $\begin{array}{l}\text { Analyzed the interaction process within the Virtual Learning Environment } \\
\text { (VLE) Moodle in distance learning mode. The interaction that occurred in }\end{array}$ \\
\hline
\end{tabular}




\begin{tabular}{|c|c|}
\hline & $\begin{array}{l}\text { this VLE was not merely technical for the application of the content to be } \\
\text { studied, but involved other aspects such as empathy, use of emojis and other } \\
\text { types of interactions. In addition, an important aspect that was worked on } \\
\text { during the study by Motta (2017) was politeness rules in internet, that is, } \\
\text { rules for social interactions on the internet. The Moodle platform allowed } \\
\text { discussions in and reflections on the L2. }\end{array}$ \\
\hline $\begin{array}{l}\text { Santos } \\
(2017)\end{array}$ & $\begin{array}{l}\text { Developed an e-book to guide teachers to use digital tools for teaching L2. } \\
\text { The content of the material did not suppress the culture of the language, as } \\
\text { teachers could see ways to work on critical issues of L } 2 \text { and culture such as: } \\
\text { sexuality and local culture together with the use of L2, so it was not a tool } \\
\text { that promoted only instrumental knowledge. }\end{array}$ \\
\hline \multicolumn{2}{|l|}{ Gamification } \\
\hline Author & Synthesis \\
\hline $\begin{array}{l}\text { Gomes } \\
(2017)\end{array}$ & $\begin{array}{l}\text { Elaborated a gamified L } 2 \text { course. Participants were able to develop critical } \\
\text { reflections on the use of gamification in the teaching of L } 2 \text { beyond the mere } \\
\text { instrumental use. }\end{array}$ \\
\hline $\begin{array}{l}\text { Centenaro } \\
(2016)\end{array}$ & $\begin{array}{l}\text { Conducted three experiments with a gamified model of teaching, where } \\
\text { games were used in order to promote the teaching-learning of L2. The use } \\
\text { of gamification in L2 did not remain in the instrumental aspect, but } \\
\text { triggered a process of digital literacy. All stages of the research had dialogue } \\
\text { and interaction on the part of the researcher with the research participants, } \\
\text { which contributed to a critical education experience. }\end{array}$ \\
\hline Levay (2015) & $\begin{array}{l}\text { Analyzed games for L2 learning in early childhood education. The games } \\
\text { did not foster collaborative activities or interaction between children, and } \\
\text { had few opportunities for developing creative responses. Children were } \\
\text { more familiarized with technologies than the teachers suggesting gap in } \\
\text { teacher education for the use of digital technologies in education. }\end{array}$ \\
\hline \multicolumn{2}{|c|}{ Teacher Initial Education } \\
\hline Author & Synthesis \\
\hline $\begin{array}{l}\text { Barreto } \\
(2016)\end{array}$ & $\begin{array}{l}\text { Prioritized the use and understanding of digital technologies during the } \\
\text { qualification process of L } 2 \text { teachers, where we find that teachers are large } \\
\text { consumers of digital technologies, but still need to understand how these } \\
\text { tools can be used critically during L } 2 \text { classes, since classes elaborated by } \\
\text { future teachers during the internship period, little explored this aspect of } \\
\text { technology. At this point, we understand the importance of investing in the } \\
\text { initial qualification of teachers so that they can deal with digital } \\
\text { technologies as educational tools and not only for consumption and } \\
\text { entertainment. }\end{array}$ \\
\hline \multicolumn{2}{|c|}{ Internationalization } \\
\hline
\end{tabular}




\begin{tabular}{|l|l|}
\hline Author & Synthesis \\
\hline Tyler (2016) & $\begin{array}{l}\text { Developed a matrix of analysis of MOOCs so as to guide users in choosing } \\
\text { the MOOC according to ergonomic, linguistic and pedagogic criteria to } \\
\text { enable a better learning experience. }\end{array}$ \\
\hline
\end{tabular}

Source: Elaborated by the Authors, 2021.

The analysis of the data suggests a gap between the technological evolution and its alignment in the process of L2 learning-teaching. Few studies addressed topics such as initial teacher education, early childhood education, EA, internationalization, among other possible themes. Possibly, if the topic of technology and education were explored more closely, we could deal with the reality faced in relation to education in the Covid-19 pandemic crisis, without excluding the adverse situations that the pandemic brought.

This result reaffirms the gaps in knowledge and research mentioned earlier in this study (Han, 2018; Paiva, 2013). If we consider the moment of technological revolution (Bardeen \& Cerpa, 2015), we confirm that technology changes the modus operandi despite not being the only cause of this change. We have witnessed a way of "chasing after the loss" of years without adequate investment in research involving digital technologies in education in general and in L2 teaching in particular. Readaptation has been costly and painful, mainly because some teachers and students do not have the equipment or adequate training to explore the full potential that digital technologies have for L2 teaching-learning.

Most of the works analyzed adopt the Freirian or Vigotskian theory, both involving the question of the exchange of knowledge through dialogue, the exchange of experiences between subjects and the development of knowledge through interaction and mediation. Although interaction and dialogue have been fundamental to the theoretical construction of such works, not all have proposed or provided an open dialogue with the research participants. Many established dialogue through interviews or semi-structured questionnaires. Even in the face of such contradiction, a number of studies have shown that the dialogue between researcher and participant is essential for the promotion of digital literacy. Through the dialogical relationship, users are able to use access to information critically (Finardi, Prebianca \& Momm, 2013).

With regard to the technologies chosen, the active presence of the teacher is essential for the critical use of digital technologies for L2 teaching-learning. This is because most of the technologies adopted for research depended on the teacher's role as mediator, content selector among other functions. Thus, we understand that technologies alone do not replace the presence of the teacher, despite the accessibility of a wide variety of information and contents online. Digital technologies are not independent of the human element for teaching. However, we observed that when it comes to mobile learning, many apps offer a structural, instrumental, autonomous L2 learning process. If used indiscriminately, these applications can give the false sensation of knowledge acquisition, therefore, promoting the semi-formation. The data in the study corroborates Vieira and Finardi (2018) in that technology in and by itself does not lead to autonomous L2 learning.

Some studies were conducted with paid apps or high-cost tools, as is the case with Vogt (2015) 
and Rapaport (2016). Considering that technological development can create/increase social inequalities, it is necessary to think of free and easily accessible alternatives to insert the use of technologies in the teaching-learning of L2. In the remote education mode experienced after the pandemic, for example, inequalities have become even more evident calling for wider inclusion and access.

In the case of Vogt (2015), it became evident the need to work on digital literacy strategies with teachers who had a tool with great potential and was used predominantly for expository classes with little interaction from students. Confirming Coscarelli's (2017) finding that the lack of knowledge of strategies and methodologies for the use of technological tools in the classroom can reduce innovative tools with great potential to an instrumental use whereby students are mere spectators and recipients of transmitted knowledge.

Although it did not lead to an experiment with a specific app for L2 teaching-learning, the work of Lopes (2018) addresses culture in L2. The movement to approach the other involved topics such as religion, holidays, parties and typical foods, among others, bringing the idea of expanding the horizons of identity and the possibility of building new meanings (Jordão, 2005 ; 2006). This strategy is essential to avoid semiformation, moving away from the learning of codes and rules only or mostly to incorporate a reflection on culture.

Only one study showed concern for the acquisition of L2 in the EA modality (Caramano, 2017) thus suggesting the need to broaden the focus to research in EA contexts. In addition, Caramano's study (2017) shows a deep concern with education through L2 teaching-learning in a way that suggests that the teaching of a language does not focus only on the interests of the market. We agree with this perspective, because L2 cannot be understood as a product aimed at consumption, because in addition to the prominence in the job market, it is the formation of the subject that is at stake (Jordão, 2005; 2006).

Levay's study (2015) showed a weakness in the construction of its theoretical foundation, but pointed out the need to create means for teachers to find L2 teaching-learning-use games to teach children. This concern was addressed by Finardi, Vieira and Leão (2019) when preparing an evaluation matrix for educational and entertainment L2 games. Levay's work (2015) is also relevant for pointing out the problem of understanding digital technologies among teachers and students suggesting the deliberate use of digital technologies for various purposes prematurely.

We noticed a gap in studies addressing the initial teacher education, such as that of Barreto (2016). Perhaps, this is one of the most important lines of research once it is related to the formation of society. The presence of the teacher is an important mediator in the process of content access and interpretation though the author makes the important caveat that teachers are more consumer of digital technology than mediators.

Another gap we identified in the production of works related to the use of technology in L2 teaching-learning is that of internationalization. Tyler (2016) was the only study identified, relating the possibility of exchanging cultural experiences among L2 learners. Though not part of the corpus analysis, we also highlight the possibilities of internationalization through digital technologies in virtual exchanges as pointed out by Finardi and Guimrãees (2020) on a recent paper discussing the possibilities of the Collaborative Online International (COIL) 
approach for the Global South in the aftermath of the pandemic.

Despite the evidence of digital technologies promoting easy access to information and diverse content, Botero (2017), Honorato (2018), Levay (2015), Rapaport (2016) and Roppel (2017) analyzed tools that demonstrate a movement opposite to this logic. In other words, the resources presented by the authors are scarce in content and in approaches to the culture and subjectivity of languages, which is detrimental to the formative process.

In addition, most of the tools analyzed in the content analysis required the mediation of the teacher to prevent the reinforcement of the totalitarian and semi-formative character of digital technologies. Tools, if used independently and only instrumentally, work against critical thinking thus pointing to the conclusion that it is necessary to invest in the human part of technology, that is, in how we use them and teach and learn with them.

We found that many works address specific tools, but we did not find studies on social networks, such as Facebook, Twitter, Whatsapp, etc. These spaces enable the circulation of false information, virtual violence and hate messages and as such, these environments cannot go unnoticed by the educator, as this is where the process of domination and dissemination of ideologies occur (Adorno \& Horkheimer, 1947).

The works of Raimundo (2017), Rech (2018), Mello (2018) and Sgorla (2016) did not test digital technologies, however they sought to understand the views of teachers and students using digital technologies. They take an important step towards developing research and understanding the use of digital tools in the teaching-learning of L2. For the emergency situation we find ourselves in, perhaps, it is the time to reflect about technologies and methodologies that are aligned with the challenges encountered in our historical path. Therefore, we understand that this is not the time to isolate technology from the human element by analyzing them separately, but together, as both are no longer separated at the current stage of society's evolution.

Another common factor perceived in the works analyzed are the difficulties to incorporate technologies in education as shown by Finardi et al. (2014), Prebianca et al. (2014) and Prebianca, Vieira and Finardi (2014). In that regard, we suggest that studies such as this could build the mass of critical voices raised at the importance of teacher education to meet the challenges of contemporary times.

Taken together, results of this study suggest the need for more research on the critical use of technologies in L2 teaching-learning-use with a special emphasis on the formation potential of technologies on the one hand and its danger of deformation on the other. Also, we conclude with a call for more investment in the education in general and in teacher education in particular with a focus on the potential of technology for the information of society in this process.

\section{Acknowledgement}

The work was supported in part by the Fundação de Amparo à Pesquisa do Espírito Santo,Brazil (FAPES) - Finance Code 001.

The work was supported in part by Cnpq, Bolsa de Produtividade em Pesquisa- Finance Code 001 . 


\section{References}

Adorno, T. (1995). Educação e Emancipação. Transalated by: Wolfgang Leo Maar. Rio de Janeiro: Paz e Terra.

Adorno, T. W. (2000). Educação e emancipação. Rio de Janeiro: Paz e Terra.

Adorno, T. W. (1992). Teoria da Semicultura. Trad. de Newton Ramos-de- Oliveira. Araraquara: UNESP. (mimeo).

Adorno, T. W. (2002) Indústria cultural e sociedade. São Paulo: Paz \& Terra.

Adorno, T. W., \& Horkheimer, M. (2002). Indústria cultural: o iluminismo como mistificação das massas. In: Adorno, T.W. (2002). Indústria cultural e sociedade. São Paulo: Paz \& Terra. p. 7-80.

Arruda, E. P. (2013). Ensino e aprendizagem na sociedade do entretenimento: desafios para a formação docente. Educação (PUCRS. Impresso), 36, 232-239.

Bardeen, M., \& Cerpa, N. (2015). Editorial: Technological Evolution in Society - The Evolution of Mobile Devices. Journal of Theoretical and Applied Electronic Commerce Research, 10(1), 1-7. https://doi.org/10.4067/S0718-18762015000100001

Bardin, L. (2011) Análise de conteúdo. Tradução Luís Antero Reto, Augusto Pinheiro. -- São Paulo: Edições 70.

Barreto, M. V. (2016). The E-book is on The Tablet: Novas Midias, Velhas Práticas no Ensino de Inglês? Dissertação (Mestrado em Educação). Programa de Pós-Graduação em Educação. Centro de Ciências da Educação. Universidade Federal de Santa Catarina. Florianópolis.

Botero, M. T. N. (2017). O Impacto das Tecnologias Digitais na Produção de Material Didático para a Língua Espanhola no Brasil. Dissertação (Mestrado em Educação e Tecnologias Digitais) - Centro Universitário Internacional, UNINTER, Curitiba, Paraná.

Bruns, A. (2006) Towards Produsage: Futures for User-Led Content Production. In: Sudweeks, Fay and Hrachovec, Herbert and Ess, Charles, Eds. Proceedings Cultural Attitudes towards Communication and Technology. Tartu (Estonia), 275-284.

Caramano, E. S. S. (2017). Proposta de Videoaulas como Organizadores Prévios para uma Aprendizagem Significativa no Ensino de Inglês na EJA. (Mestrado em Educação). Faculdade de Ciências. Universidade Federal Paulista. Bauru. São Paulo.

Castro, A. L. S., Hildeblando Júnior, C. A., \& Finardi, K. R. (2019). Teachers and Students Online but Disconnected. INTED2019 Proceedings, 420-427. https://doi.org/10.21125/ inted.2019.0186

Castro, A. L. S., Mariano, L. S., \& Finardi, K. R. (2018). As Novas Tecnologias no Ensino-Aprendizado de L2: Refletindo a Partir de Olhares de Professores, 3, 71-87. https://doi.org/10.35819/linguatec.v3.n2.a3290

Centenaro, F. K. (2016). Investigação de uma Abordagem Pedagógica para o Ensino de Língua Inglesa por Meio de Jogos Digitais. Dissertação (Mestrado em Tecnologias Educacionais em Rede). Centro de Educação. Universidade Federal de Santa Maria. Santa Maria. Rio Grande do Sul.

Co, E. P., Amorim, G. B., \& Finardi, K. R. (2020). Ensino de Línguas em Tempos de 
Pandemia: Experiências com Tecnologia em Ambientes Virtuais. Revista Docência e Cibercultura, 4, 112-140. https://doi.org/10.12957/redoc.2020.53173

Coscarelli, C. V. (2017). Alfabetização e Letramento Digital. In: Ribeiro, A. E; Coscarelli, C. V. (Org.). Letramento Digital: Aspectos Sociais e Possibilidades Pedagógicas. Minas Gerais. Belo Horizonte.

D'ambrosio, I. S. S. (2017) História em quadrinhos digital como estratégia de desenvolvimento da escrita em inglês. Dissertação (Mestrado em Educação) - Universidade Federal de Sergipe, São Cristóvão.

Diniz De Figueiredo, E. H., \& Martinez, J. (2019). The locus of enunciation as a way to confront epistemological racism and decolonize scholarly knowledge. Applied Linguistics. https://doi.org/10.1093/applin/amz061

Dornyei, Z. (2016). Research methods in applied linguistics: Quantitative, qualitative and mixed methodologies. Oxford: Oxford University Press.

Fadini, K. (2016). Formação inicial de professores de inglês do e para o século XXI:os papéis da língua e da tecnologia. Dissertação (Mestrado) - Programa de Pós-Graduação em Linguística. Universidade Federal do Espírito Santo, Vitória.

Finardi, K. R., \& Guimaraes, F. (2020). Internationalization and the Covid-19 Pandemic: Challenges and Opportunities for the Global South. Journal of Education, Teaching and Social Studies, 2, 1-15. https://doi.org/10.22158/jetss.v2n4p1

Finardi, K. R., Leão, R. G., \& Amorim, G. B. (2016). Mobile Assisted Language Learning: Affordances and Limitations of Duolingo. Education and Linguistics Research, 2(2), 48-65. https://doi.org/10.5296/elr.v2i2.9842

Finardi, K. R., \& Mendes, A. R. M. (2014). Formação de Professores para Uso de Metodologias Ativas e Híbridas Através do Mall. Hipertextos Revista Digital, 16, 52-73.

Finardi, K. R., Leão, R. G., \& Pinheiro, L. M. S. (2016). English in Brazil: Insights from the Analysis of Language Policies, Internationalization Programs and the CLIL Approach. Education and Linguistics Research, 2(1), 54-68. https://doi.org/10.5296/elr.v2i1.9150

Finardi, K. R., \& Porcino, M. C. (2014). Tecnologia e Metodologia no Ensino de Inglês: Impactos da Globalização e da Internacionalização. Ilha do Desterro, 66, 239-284. https://doi.org/10.5007/2175-8026.2014n66p239

Finardi, K. R., Prebianca, G. V. V., \& Momm, C. F. (2013). Tecnologia na Educação: o caso da internet e do Inglês como linguagens de inclusão. Cadernos do IL, (46), 193-208. https://doi.org/10.22456/2236-6385.35931

Finardi, K. R., \& Teixeira, D. (2013). Information Technology and Communication at UFES. In: International Conference of Interactive Computer Aided Blended Learning, 2013, Florianopolis. International Conference of Interactive Computer Aided Blended Learning. Florianopolis: Instituto Federal de Santa Catarina, 1, 79-82.

Finardi, K. R., Teixeira, D., Prebianca, G. V. V., \& Santos Júnior, V. P. (2014). Information Technology and Communication in Education: Two Sides of the Coin in Brazil. International Journal of Recent Contributions from Engineering, Science \& IT (iJES), 2, 21-25.

Finardi, K. R., \& Vieira, G. V. (2017). Mobilidade e Ensino-Aprendizagem de Línguas 
Estrangeiras. Polifonia Estudos da Linguagem, 24(351), 32-49.

Finardi, K; Vieira, G; Leão, R. G. (2019). Uma Proposta de Matriz Avaliação de Jogos Digitais para o Ensino-aprendizagem-uso de Língua Adicional. Pelotas-RS: Linguagem \& Ensino, 22(4), 1174-1198. https://doi.org/10.15210/rle.v22i4.16288

Freire, P. (2011). Pedagogia da Autonomia: Saberes Necessários à Prática Educativa. São Paulo: Paz e Terra.

Gomes, A. F. (2017). Material Didático Digital, Games e Gamification: Conexões no Design para Implementação de Cursos Online. Dissertação (Mestrado em Tecnologias Educacionais em Rede). Centro de Educação. Universidade Federal de Santa Maria. Santa Maria. Rio Grande de Sul.

Han, B. C. (2017). Sociedade da Transparência. Petrópolis, RJ. Vozes.

Han, B. C. (2018). No Enxame. Petrópolis, RJ. Vozes.

Honorato, A. A. (2018). Duolingo no Ensino-Aprendizagem de Inglês com Foco no Vocabulário: Potencialidades e Limitações. Dissertação (Mestrado em Ensino e Processos Formativos). Instituto de Biociências, Letras e Ciências Exatas. Universidade Estadual Paulista "Júlio de Mesquita Filho". São José do Rio Preto. São Paulo.

Jordão, C. M. (2014). ILA - ILF - ILE - ILG: Quem dá conta? Revista Brasileira de Linguística Aplicada, 14(1), 13-40. https://doi.org/10.1590/S1984-63982014000100002

Jordão, C. M. (2006). O Ensino de Línguas Estrangeiras - de código a discurso. In: VAZ Boni, Valéria. (Org.). Tendências Contemporâneas no Ensino de Línguas. União da Vitória: Kaygangue.

Jordão, C. (2005). A língua estrangeira e a formação do indivíduo. In: PARANÁ. Secretaria de Estado da Educação - Departamento de Ensino Fundamental. Diretrizes Curriculares Estaduais - Língua Estrangeira Moderna (versão preliminar). Curitiba: SEED/PR.

Leão, R. G., Taquini, R., \& Finardi, K. R. (2019). The Role of Internet/ Youtube in the Socialization/ Popularization of Science in Brazil. Education and Linguistics Research, 5(2), 159-174. https://doi.org/10.5296/elr.v5i2.15935

Levay, P. B. (2015). Jogos Digitais no Ensino e Aprendizagem de Inglês para Crianças. Dissertação (Mestrado em Tecnologia e Gestão de Educação a Distância). Unidade Acadêmica de Educação a Distância e Tecnologia. Universidade Federal Rural de Pernambuco. Recife.

Lima, J. C. (2016). Uma Análise do Ensino de Lingua Inglesa por Meio do Uso das Tecnologias Digitais da Informação e Comunicação. Tese (Doutorado em Educação). Faculdade em Filosofia e Ciências. Universidade Estadual Paulista. Marília. São Paulo.

Liz, N. (2015). Tecnologia Móvel no Ensino e Aprendizagem de Língua Inglesa na Escola. Dissertação (Mestrado em Ensino de Ciências Humanas, Sociais e da Natureza). Universidade Tecnológica Federal do Paraná. Londrina. Paraná

Lopes, P. R. (2018). Cultura na Palma da Mão: Potencialidades do Aplicativo "Minha Espanha" para Aprender sobre a Cultura Espanhola. Dissertação (Mestrado em Ensino e Processos Formativos). Instituto de Biociências, Letras e Ciências Exatas. Universidade Estadual Paulista "Júlio de Mesquita Filho". São José do Rio Preto. São Paulo 


\section{Macrothink}

Education and Linguistics Research ISSN 2377-1356 2021, Vol. 7, No. 1

Loureiro, R. (2007). Aversão à teoria e indigência da prática. Revista Educação e Sociedade (Campinas), 28(99), 522-541. https://doi.org/10.1590/S0101-73302007000200012

Maar, W. L. (1995). Prefácio. Educação e Emancipação. Tradução do alemão: Wolfgang Leo Maar. Rio de Janeiro: Paz e Terra.

Maar, W. L. (2003) Adorno, Semiformação e Educação. Educação e Sociedade. Campinas, 24(83), 459-476. https://doi.org/10.1590/S0101-73302003000200008

Marconi, M. A., \& Lakatos, E. A. (2010). Fundamentos de Metodologia Científica. 7 ed. São Paulo, SP. Atlas S.A.

Mello, E. C. F. (2018). O Uso de Tecnologias nas Aulas de Língua Inglesa no Ensino Fundamental II em Foz do Iguaçu/PR. Dissertação (Mestrado em Ensino) - Universidade Estadual do Oeste do Paraná, Foz do Iguaçu.

Mendes, A. R. M. (2017). Abordagem Híbrida na Formação Inicial de Professores de Inglês: Integrando as Novas Tecnologias. Dissertação (Mestrado em Linguística). Programa de Pós-graduação em Linguística. Universidade Federal do Espírito Santo. Vitória, Espírito Santo.

Mendes, A. R. M., \& Finardi, K. R. (2018). Linguistic Education Under Revision: Globalization and EFL Teacher Education in Brazil. Education and Linguistics Research, 4, 45-64. https://doi.org/10.5296/elr.v4i1.12831

Mendes, A. R. M., \& Finardi, K. R. (2020). Integrating Digital Technologies in Brazilian English Language Teacher Education Through Blended Learning. Educação Em Revista (Online). https://doi.org/10.1590/0102-4698233799

Mesquita, S. S. M. (2016). O Blog como Recurso Pedagógico para o Ensino da Língua Espanhola. Dissertação (Mestrado em Ensino Tecnológico) - Recursos para o Ensino Técnico e Tecnológico. Instituto Federal de Educação, Ciência e Tecnologia do Amazonas. Manaus.

Motta, M. N. (2017). Mediação Docente em Fóruns Online de Discussão em Curso de Letras - Espanhol, na Modalidade Ead, À Luz do Modelo de Comunidade de Investigação/Aprendizagem. Dissertação (Mestrado em Educação e Tecnologia). Instituto Federal de Educação, Ciência e Tecnologia Sul-rio-grandense. Pelotas. Rio Grande do Sul.

Paiva, V. L. M. O. (2013). A formação do professor para uso da tecnologia. In Silva, K. A., Daniel, F. G., Kaneko-Marques, S. M., \& Salomão, A. C. B. (Orgs) A formação de professores de linguas: Novos Olhares - v 2. Campinas: Pontes Editores, pp. 209-230.

Petry, F. B. (2015). Experiência e Formação em Theodor W. Adorno. Educação e Filosofia Uberlândia. https://doi.org/10.14393/REVEDFIL.issn.0102-6801.v29n57a2015-p455a488

Ponte, C. (2017). Crescendo Entre Culturas Digitais nas Últimas Décadas. In LIMA, N. L., Stengel, M., Nobre, M. R., Dias, V. C. (Orgs) Juventude e Cultura Digital. Diálogos Interdisciplinares. Ed. 1. V. Belo Horizonte - MG, Artesã. pp. 33-45.

Prebianca, G. V; Santos Junior, V. P. Dos; \& Finardi, K. R. (2014). Analysis of an educational software for language learning: insights from the Theory of Structural Cognitive Modifiability and Human-Computer Interaction. DELTA. Documentação de Estudos em Linguística Teórica e Aplicada (PUCSP. Impresso), 30, 95-114. https://doi.org/10.1590/ S0102-44502014000100006 


\section{Ml Macrothink}

Education and Linguistics Research ISSN 2377-1356 2021, Vol. 7, No. 1

Prebianca, G., Vieira, M. F. V., \& Finardi, K. R. (2014). Instrução Gramatical na Era da Tecnologia: Investigando Diferentes Abordagens para o Ensino-Aprendizagem de Inglês no Ensino Médio Integrado. Signum: Estudos da Linguagem, 17, 181-214. https://doi.org/ $10.5433 / 2237-4876.2014 \mathrm{v} 17 \mathrm{n} 1 \mathrm{p} 181$

Raimundo, C. M. (2017). Uso, Integração e Apropriação de Tecnologias e Mídias Digitais nas Aulas de Inglês nas Escolas Municipais de Curitiba. Dissertação (Mestrado em Educação: Teoria e Prática de Ensino). Setor de Educação. Universidade Federal do Paraná. Curitiba. Paraná.

Rapaport, R. (2016). Mobile Learning: O Professor Frente ao "Como Utilizar" Aplicativos Móveis no Ensino do Inglês do Século XXI. Dissertação (Mestrado em Educação e Novas Tecnologias). Centro Universitário Internacional. UNINTER. Curitiba. Paraná.

Rech, S. A. (2018). Ensino e Aprendizagem da Língua Inglesa Mediados pelas Tecnologias Digitais no IFs do Sul de Santa Catarina: Reflexões a Partir da Perspectiva de CALL. Dissertação (Mestrado em Educação). Programa de Pós-Graduação em Educação. Universidade do Extremo Sul Catarinense. Criciúma.

Roppel, S. M. (2017). O Uso das Tecnologias de Informação e Comunicação no Ensino de Língua Espanhola: Estudo do Aplicativo Duolingo. Dissertação (Mestrado em Educação e Novas Tecnologias). Centro Universitário Internacional. UNINTER. Curitiba. Paraná.

Santos, D. H. (2017). As Práticas de Mediação Pedagógica de Tutoria para o Desenvolvimento da Expressão Oral da Língua Espanhola na Modalidade a Distância: Um Guia de Auxílio. Dissertação (Mestrado em Educação e Novas Tecnologias). Centro Universitário Internacional. UNINTER. Curitiba. Paraná.

Selwyn, N. (2014). Digital Technology and the Contemporary University. Degrees of Education. Londres, Reino Unido: Routledge. https://doi.org/10.4324/9781315768656

Sgorla, K. (2016). Inovação Tecnológica e Práticas Pedagógicas: A Relação Existente entre as Tecnologias de Informação e Comunicação e o Professor de Língua Inglesa da Rede Estadual de Ensino do Município de Foz do Iguaçu/PR. Dissertação (Mestrado em Ensino). Universidade Estadual Oeste do Paraná. Foz do Iguaçu. Paraná.

Tyler, J. R. (2017). Inglês Tecnologia e Internacionalização da Educação Superior: Evidências e Reflexões a Partir da Análise de Moocs. Dissertação (Mestrado em Educação). Programa de Pós-Graduação em Educação. Universidade Federal do Espírito Santo. Vitória.

Vieira, G., \& Finardi, K. R. (2018). The Case of EFL: Does Technology Lead to Learning? Raido, 12, 197-210. https://doi.org/10.30612/raido.v12i30.9390

Vigotsky, L. S. (1991). A Formação Social da Mente: O Desenvolvimento dos Processos Psicológicos Superiores. Trad. José Cipolla Neto; Luis Silveira Menna Barreto; Solange Castro Afeche. São Paulo: Martins Fontes.

Vogt, P. O. (2015). Uso Pedagógico da Lousa Digital Interativa: O Caso da Prática Docente em Língua Estrangeira. Dissertação (Mestrado em Educação). Setor de Ciência Humanas. Universidade Federal do Paraná. Curitiba. Paraná.

Williamson, B., Eynon, R., \& Potter, J. (2020). Pandemic Politics, Pedagogies and Practices: Digital Technologies and Distance Education During the Coronavirus Emergency. Learning, 


\section{Macrothink}

Media and Technology, 45(2), 107-114. https://doi.org/10.1080/ 17439884.2020.1761641

Wyatt, S. (2020). Preparing Students for a Digital Society. Digitalisation in International Education. Amsterdam, Special Edition.

\section{Notes}

Note 1. We use the term additional language (L2) to refer to any language except the first/native language (L1)

Note 2. https://globoplay.globo.com/big-brother-brasil/t/mh6BzqCQVy

Note 3. In this example a Brazilian nurse shows in her social networks that she does not feel safer with the vaccine, also she apparently does not wear mask inside the hospital. https://g1.globo.com/es/espirito-santo/noticia/2021/01/25/mp-vai-apurar-caso-de-enfermeiraque-fez-video-debochando-de-vacina-contra-covid-19.ghtml

\section{Copyright Disclaimer}

Copyright reserved by the author(s).

This article is an open-access article distributed under the terms and conditions of the Creative Commons Attribution license (http://creativecommons.org/licenses/by/4.0/). 